\title{
Sperm Quality and Oxidative-Antioxidant Profile in Men Living in Different Regions of Siberia
}

\author{
Nadezhda A. Kurashova, PhD, ScD*; Bair G. Dashiev PhD; \\ Lyubov I. Kolesnikova, $\mathrm{PhD}, \mathrm{ScD}$, Member of the RAS \\ Scientific Centre for Family Health and Human Reproduction Problems \\ Irkutsk, the Russian Federation
}

\begin{abstract}
Background: The aim of this study was to assess the sperm quality and oxidative-antioxidant profile in men living in different regions of Siberia.

Materials and Methods: The study involved 125 men of reproductive age: 40 men (mean age of 24.8 years) living in UlanUde, 35 men (mean age of 24.1 years) in Irkutsk, and 50 men (mean age of 24.6 years) in Novosibirsk. All men belonged to the Caucasian race and were physically healthy. Methods of standard clinical examination of fertile and infertile men included: an ultrasonic scan of scrotum and prostate, macroscopic and microscopic examination of ejaculate, and biochemical analysis. The semen analysis was performed in accordance with the WHO recommendations (2010). The study of sperm quality included measuring the volume and $\mathrm{pH}$ of the ejaculate, the concentration of spermatozoa, the proportion of motile sperm of categories $\mathrm{A}$ and $\mathrm{B}$, and lipid peroxidation-antioxidant activity products. Of the participants in the study, the group of somatically healthy men living in Irkutsk had the highest sperm count (mln per ml): 1.5 times more than men in Novosibirsk and 1.3 times more than men in Ulan-Ude. At the same time, in the group of men in Irkutsk, a significant increase in the concentration of $\alpha$-tocopherol was revealed: 1.6 times more than the men in Ulan-Ude and 1.8 times more than the men in Novosibirsk.

Conclusion: The conducted studies of the quality of ejaculate and the characteristics of LPO processes in men from different cities of Siberia show that place of residence and ecological-geographical position are not the main reasons determining reproductive dysfunction, but can be important factors affecting the functioning of the reproductive system and determining the heterogeneity of male infertility in conditions of anthropogenic pressure. (International Journal of Biomedicine. 2020;10(4):369-372.)
\end{abstract}

Key Words: antioxidant defense $\bullet$ men $\bullet$ spermatogenesis $\bullet$ ethno groups

\section{Abbreviations}

AOD, antioxidant defense; CD, conjugated dienes; LPO, lipid peroxidation; MDA, malondialdehyde; ROS, reactive oxygen species; TAA, total antioxidant activity; TBARs, thiobarbituric acid reactants.

\section{Introduction}

Human health is formed as a result of the complex interaction between the hereditary and constitutional characteristics of an organism and between the organism and nature and society. Geographic and ethnic variability of the

*Corresponding author: Nadezhda Kurashova, PhD, ScD. Scientific Centre for Family Health and Human Reproduction Problems, Irkutsk, the Russian Federation. E-mail: nakurashova@, yandex.ru norm and pathology play an important role. ${ }^{(1-3)}$ The results of many years of fundamental and clinical research indicate that differences exist in the most important physiological constants of the body in the functioning of the reactions of the neuro-immune-endocrine system to the impact of inadequate exogenous and endogenous factors, as well as in the morphological characteristics and adaptive shifts in various environmental conditions. ${ }^{(4-8)}$ Male subfertility, deviations from the norm in sperm counts, and infertility are very common phenomena at the present time. ${ }^{(8,9)}$ The works of foreign researchers of the last century, as well 
as contemporaries, indicate that the lack of vitamins and microelements is one of the reasons for the progressive decline in spermatogenesis indicators. ${ }^{(1,8,10)}$ At all times, nutrition and the ability to reproduce offspring have been closely interrelated. It is known that due to changes in the habitat, and to the nature of nutrition and lifestyle in a modern person, there is a lack of vitamins and microelements (or a violation of their metabolism), which is largely responsible for disorders of the reproductive system. ${ }^{(2,4)}$ Another factor affecting the decrease in male fertility is the hyperproduction of ROS..$^{(11-13)}$ ROS damage the sperm membrane, which leads to a decrease in sperm quality. ${ }^{(10,12)}$ At the stationary level, lipid peroxidation processes are maintained due to the work of the AOS, which includes enzymatic and non-enzymatic links. Disruption of antioxidant protection leads to the development of free radical damage to the structure of spermatogenesis cells, including the DNA membrane and intracellular proteins. ${ }^{(14-16)}$ As a result, there is a violation of the structure and functional qualities of spermatozoa, which subsequently leads to their death. The ratio of the activity of oxidative processes and antioxidant protection largely determines the intensity of metabolism, the adaptive capabilities of the organism and the risk of various pathological conditions. ${ }^{(7,18,19)}$ Since the study of regional features that affect the health status of the population living in a certain territory is of practical importance for maintaining the health of the population, the study of adaptive reactions in practically healthy men living in various regions of Siberia is of undoubted relevance.

The aim of this study was to assess the sperm quality and oxidative-antioxidant profile in men living in different regions of Siberia.

\section{Materials and Methods}

The study involved 125 men of reproductive age: 40 men (mean age of 24.8 years) living in Ulan-Ude, 35 men (mean age of 24.1 years) in Irkutsk, and 50 men (mean age of 24.6 years) in Novosibirsk. All men belonged to the Caucasian race and were physically healthy. Methods of standard clinical examination of fertile and infertile men included: an ultrasonic scan of scrotum and prostate, macroscopic and microscopic examination of ejaculate, and biochemical analysis. The semen analysis was performed in accordance with the WHO recommendations. ${ }^{(20)}$ The study of sperm quality included measuring the volume and $\mathrm{pH}$ of the ejaculate, the concentration of spermatozoa, the proportion of motile sperm of categories A and B, and LPO-AOD products.

In the seminal fluid of the examined men, the content of $\mathrm{CD}$ (primary oxidation products) and TBARS, end products of LPO, was determined by the methods of V. Gavrilov et al ${ }^{(21,22)}$ The level of $\alpha$-tocopherol and retinol was estimated by the method of R. Ch.Chernyauskene et al., ${ }^{23)}$ TAA according to GI Klebanov et al. ${ }^{(24)}$

Statistical analysis was performed using STATISTICA 6.1 software (Stat-Soft Inc., USA). The normality of distribution of continuous variables was tested by onesample Kolmogorov-Smirnov test. Baseline characteristics were summarized as mean \pm standard deviation (SD), median
(Me) and interquartile range (IQR; 25th to 75th percentiles). Multiple comparisons were performed with one-way ANOVA with Tukey's pairwise comparisons. A value of $P<0.05$ was considered significant.

The study was carried out in compliance with Ethical Principles for Medical Research Involving Human Subjects, Adopted by the 18th WMA General Assembly, Helsinki, Finland, June 1964, and amended by the 64th WMA General Assembly, Fortaleza, Brazil, October 2013. The study was approved by the Ethics Committee of the Scientific Center for Family Health and Human Reproduction Problems. Written informed consent was obtained from each patient.

\section{Results and Discussion}

Of the participants in the study, the group of somatically healthy men living in Irkutsk had the highest sperm count ( $\mathrm{mln}$ per ml): 1.5 times more than men in Novosibirsk and 1.3 times more than men in Ulan-Ude. At the same time, in the group of men in Irkutsk, a significant increase in the concentration of $\alpha$-tocopherol was revealed: 1.6 times more than the men in Ulan-Ude and 1.8 times more than the men in Novosibirsk (Table 1).

Table 1.

Indicators of spermatogenesis and $L P O-A O D$ products in men from different cities of Siberia

\begin{tabular}{|c|c|c|c|c|}
\hline Index & $\begin{array}{c}\text { Irkutsk } \\
\mathrm{n}=35(1)\end{array}$ & $\begin{array}{c}\text { Novosibirsk } \\
n=50(2)\end{array}$ & $\begin{array}{l}\text { Ulan-Ude } \\
\mathrm{n}=40(3)\end{array}$ & $P$-value \\
\hline Volume, ml & $\begin{array}{c}3.9 \pm 1.56 \\
3.5 \\
2.8 ; 5.00\end{array}$ & $\begin{array}{c}3.6 \pm 1.79 \\
3.21 \\
{[2.28 ; 4.41]}\end{array}$ & $\begin{array}{c}3.34 \pm 0.94 \\
3.32 \\
{[2.82 ; 3.74]}\end{array}$ & $\mathrm{P}=0.2757$ \\
\hline $\begin{array}{l}\text { Sperm count, } \\
\mathrm{mln} / \mathrm{ml}\end{array}$ & {$\left[\begin{array}{c}82.9 \pm 43.04 \\
80.6 \\
{[51.42 ; 113.2]}\end{array}\right.$} & $\begin{array}{c}54.04 \pm 47.7 \\
40.28 \\
{[19.46 ; 67.4]}\end{array}$ & $\begin{array}{c}63.32 \pm 38.97 \\
51.56 \\
{[34.25 ; 80.67]}\end{array}$ & $\begin{array}{l}\mathrm{P}=0.0127 \\
\mathrm{P}_{1-2}=0.0093 \\
\mathrm{P}_{1-3}=0.1339 \\
\mathrm{P}_{2-3}=0.5786\end{array}$ \\
\hline $\begin{array}{l}\text { Category } \\
\mathrm{A}+\mathrm{B}, \%\end{array}$ & $\begin{array}{c}51.59 \pm 17.42 \\
52.00 \\
{[40.0 ; 67.0]}\end{array}$ & {$\left[\begin{array}{c}48.26 \pm 29.67 \\
47.95 \\
{[22.95 ; 74.75}\end{array}\right]$} & $\begin{array}{c}57.69 \pm 15.96 \\
55.96 \\
{[44.73 ; 68.33]}\end{array}$ & $\mathrm{P}=0.1511$ \\
\hline $\begin{array}{l}\mathrm{CD}, \\
\mu \mathrm{mol} / 1\end{array}$ & $\begin{array}{c}1.28 \pm 0.82 \\
1.26 \\
{[0.52 ; 1.92]}\end{array}$ & $\begin{array}{c}1.25 \pm 0.97 \\
0.92 \\
{[0.79 ; 1.29]}\end{array}$ & $\begin{array}{c}1.26 \pm 0.68 \\
1.16 \\
{[0.70 ; 2.08]}\end{array}$ & $\mathrm{P}=0.9870$ \\
\hline $\begin{array}{l}\text { MDA, } \\
\mu \mathrm{mol} / 1\end{array}$ & $\begin{array}{c}1.01 \pm 0.69 \\
0.80 \\
{[0.71 ; 1.12]}\end{array}$ & $\begin{array}{c}0.96 \pm 0.32 \\
0.87 \\
{[0.69 ; 1.17]}\end{array}$ & $\begin{array}{c}1.02 \pm 0.36 \\
1.00 \\
{[0.71 ; 1.23]}\end{array}$ & $\mathrm{P}=0.8047$ \\
\hline $\begin{array}{l}\text { TAA, } \\
\text { stand. units }\end{array}$ & $\begin{array}{c}3.23 \pm 1.46 \\
3.03 \\
{[2.32 ; 4.94]}\end{array}$ & $\begin{array}{c}2.68 \pm 1.78 \\
1.96 \\
{[1.41 ; 3.80]}\end{array}$ & $\begin{array}{c}4.05 \pm 1.76 \\
3.56 \\
{[2.94 ; 5.54]}\end{array}$ & $\begin{array}{l}\mathrm{P}=0.0010 \\
\mathrm{P}_{1-2}=0.3058 \\
\mathrm{P}_{1-3}=0.0948 \\
\mathrm{P}_{2-3}=0.0006\end{array}$ \\
\hline $\begin{array}{l}\alpha \text {-tocopherol, } \\
\mu \mathrm{mol} / \mathrm{l}\end{array}$ & $\begin{array}{c}5.34 \pm 2.66 \\
3.99 \\
{[3.56 ; 6.82]}\end{array}$ & $\begin{array}{c}3.29 \pm 1.74 \\
2.53 \\
{[2.01 ; 4.47]}\end{array}$ & $\begin{array}{c}2.97 \pm 0.95 \\
2.82 \\
{[2.15 ; 3.62]}\end{array}$ & $\begin{array}{l}\mathrm{P}=0.0000 \\
\mathrm{P}_{1-2}=0.0000 \\
\mathrm{P}_{1-3}=0.0000 \\
\mathrm{P}_{2-3}=0.6981\end{array}$ \\
\hline
\end{tabular}

The data obtained confirm the theses of other researchers regarding the fact that the deficiency of $\alpha$-tocopherol, the most important fat-soluble vitamin, exhibiting membraneprotective and antimutagenic activity, is primarily manifested by a reduced sperm count. Also, the deficiency of $\alpha$-tocopherol 
leads to a decrease in the volume of ejaculate, which was demonstrated in the groups of men in Novosibirsk and UlanUde, in comparison with men in Irkutsk. Considering that the sperm membrane consists of lipids, and $\alpha$-tocopherol plays a key role in the inhibition of LPO processes under the action of ROS, it can be assumed that the results obtained indicate the reliable functioning of the adaptive-protective mechanisms of the body in men living in Irkutsk.

Men in Ulan-Ude are characterized by a higher level of TAA: 1.5 times higher than men in Novosibirsk and 1.2 times higher than men in Irkutsk (Table 1). Considering that the group of men in Ulan-Ude has the lowest concentration of $\alpha$-tocopherol, the high level of TAA, which characterizes the total activity of oxidation inhibitors and the body's ability to counteract the development of free radical reactions, can be explained both by the stress of the adaptive systems and reliable functioning of specialized enzymatic and nonenzymatic components of the AOD.

The complex process of spermatogenesis requires an optimal combination of various elements, including vitamins and trace elements. The physical, mental, and sexual health of a modern man depends on the quality of food, and the nature of and adherence to the diet. In particular, lack of attention to these factors is responsible for the disorders occurring in the reproductive systems of men, because if a sufficient amount of building material does not enter the body in a timely manner, then the cells begin to use substances that are similar in chemical properties, but inappropriate. The result of such a substitution can be the formation of sperm with reduced properties. The decrease in the indicators of spermatogenesis in men, demonstrated by studies in recent years, could be caused both by the increasing impact on the human body of damaging factors found in the environment, at work and in everyday life, and by the lack of vitamins and microelements in the diet of modern men..$^{(1,7,8,10)}$ According to a comprehensive assessment of nutrition in a number of regions of the world, there has been a sharp (2-3 times) decrease in the amount of food consumed by humans. ${ }^{(12)} \mathrm{A}$ decrease in the volume of food also reduces the amount of intake of necessary nutrients - minerals, vitamins, amino acids. At present, in developed countries the physical activity of the population has decreased, which indicates a decrease in energy consumption..$^{(12)}$

The conducted studies of the quality of ejaculate and the characteristics of LPO processes in men from different cities of Siberia show that place of residence and ecologicalgeographical position are not the main reasons determining reproductive dysfunction, but can be important factors affecting the functioning of the reproductive system and determining the heterogeneity of male infertility in conditions of anthropogenic pressure.

\section{Competing Interests}

The authors declare that they have no competing interests.

This work was performed with the use of equipment of the collective research center "Centre for the development of progressive personalized health technologies" SC FHHRP, Irkutsk.

\section{References}

1. Kolesnikova LI, Kolesnikov SI, Zagarskikh EYu, Dolgikh VV, Kurashova NA, Grebenkina LA, Dolgikh MI, Vlasov BYa. [Features of lipid peroxidation and antioxidant protection in adolescent boys in Irkutsk]. Reproductive Health of Children and Adolescents. 2009;5:63-67. [Article in Russian].

2. Kolesnikova LI, Kolesnikov SI, Kurashova NA, Osadchuk LV, Osadchuk AV, Dolgikh MI, Dashiev BG, Shantanova LN. Reproductive Health and Peculiarities of Lipid PeroxidationAntioxidant Defense System in Men of the Main Ethnic Groups of the Baikal Region. Bull Exp Biol Med. 2015 Nov;160(1):32-4. doi: 10.1007/s10517-015-3091-6.

3. Fatima S, Alwaznah R, Aljuraiban GS, Wasi S, Abudawood M, Abulmeaty M, Berika MY, Aljaser FS. Effect of seminal redox status on lipid peroxidation, apoptosis and DNA fragmentation in spermatozoa of infertile Saudi males. Saudi Med J. 2020 Mar;41(3):238-246. doi: 10.15537/ smj.2020.3.24975.

4. Kurashova NA. [Assessment of the reproductive potential of the male population]. Bulletin of ESSC SB RAMS. 2014;96(2):104-109. [Article in Russian].

5. Panner Selvam MK, Finelli R, Agarwal A, Henkel R. Proteomics and metabolomics - Current and future perspectives in clinical andrology. Andrologia. 2020 Jun 29:e13711. doi: 10.1111/and.13711.

6. Murgia F, Corda V, Serrenti M, Usai V, Santoru ML, Hurt KJ, Passaretti M, Monni MC, Atzori L, Monni G. Seminal Fluid Metabolomic Markers of Oligozoospermic Infertility in Humans. Metabolites. 2020 Feb 11;10(2):64. doi: 10.3390/ metabo10020064.

7. Kolesnikova LI, Kurashova NA, Bairova TA, Dolgikh MI, Ershova OA, Natyaganova LV, et al. Features of Lipoperoxidation, Antioxidant Defense, and Thiol/Disulfide System in the Pathogenesis of Infertility in Males, Carriers of Nonfunctional Variants of GSTT1 and GSTM1 Gene Polymorphisms. Bull Exp Biol Med. 2017 Jul;163(3):378380. doi: 10.1007/s10517-017-3808-9.

8. Kurashova NA, Dolgikh MI, Ershova OA, Gavrilova OA, Osipova EV, Dashiev BG, et al. Associations of Polymorphic Variants of the Biotransformation Genes with the Components of the Glutathione System in Men with Infertility. International Journal of Biomedicine. 2017;7(3):226-230. doi: 10.21103/ Article7(3) OA13

9. Kurashova NA, Dashiev BG, Dolgikh MI, Kolesnikova LI. The Processes of Lipoperoxidation and Antioxidant Protection in Men with Different Variants of Spermograms. International Journal of Biomedicine. 2019;9(2):168-171. doi: 10.21103/Article9(2)_OA18

10. Belenkaia LV, Sholokhov LF, Kolesnikova LI. Levels of essential elements in pubic hair of men with type 1 diabetes. Endocrine Rev. 2017;38(S3):169-170.

11. Robert KA, Sharma R, Henkel R, Agarwal A. An update on the techniques used to measure oxidative stress in seminal plasma. Andrologia. 2020 Aug 19:e13726. doi: 10.1111/ and.13726. Epub ahead of print.

12. Barik G, Chaturvedula L, Bobby Z. Role of Oxidative Stress and Antioxidants in Male Infertility: An Interventional Study. J Hum Reprod Sci. 2019 Jul-Sep;12(3):204-209. doi: 10.4103/jhrs.JHRS 13518.

13. Kurashova NA, Madaeva IM, Kolesnikova LI. [Expression of heat shock proteins HSP70 under oxidative stress.]. Adv Gerontol. 2019;32(4):502-508. [Article in Russian]. 
14. Kolesnikova LI, Madaeva IM, Semenova NV, Vlasov BY, Grebenkina LA, Darenskaya MA, Dolgikh MI. Antioxidant potential of the blood in men with obstructive sleep breathing disorders. Bull Exp Biol Med. 2013 Apr;154(6):731-3. doi: 10.1007/s10517-013-2041-4.

15. Dutta S, Majzoub A, Agarwal A. Oxidative stress and sperm function: A systematic review on evaluation and management. Arab J Urol. 2019 Apr 24;17(2):87-97. doi: 10.1080/2090598X.2019.1599624.

16. Agarwal A, Sengupta P. Oxidative Stress and Its Association with Male Infertility. In Parekattil SJ, Esteves SC, Agarwal A., editors. Male Infertility: Contemporary Clinical Approaches, Andrology, ART and Antioxidants. Springer Nature Switzerland AG 2020:57-68.

17. Agarwal A, Leisegang K, Sengupta P. Oxidative stress in pathologies of male reproductive disorders. In Preedy V. editor. Pathology: Oxidative Stress and Dietary Antioxidants. Elsevier; 2020:15-27.

18. Kurashova NA, Dashiev BG, Dolgikh MI, Kudeyarova EA, Labygina AV, Bairova TA, Kolesnikova LI. Association of Lipid Peroxidation/Antioxidant System Activity with Glutathione S-Transferase P1 Polymorphisms in Infertile Men. International Journal of Biomedicine. 2019;9(4):329333. doi: 10.21103/Article9(4)_OA11
19. Kolesnikova LI, Kurashova NA, Osadchuk LV, Osadchuk AV, Dolgikh MI, et al. Parameters of Pro- and Antioxidant Status in Ejaculate of Men of Fertile Age. Bull Exp Biol Med. 2015 Oct;159(6):726-8. doi: 10.1007/s10517-015-3059-6.

20. WHOlaboratorymanual for the examination and processing of human semen - 5th ed. Available from: https://apps.who. int/iris/bitstream/handle/10665/44261/9789241547789 eng. pdf;jsessionid=46F8915182775DD661AE4D5247CDA162?s equence $=1$

21. 21.Gavrilov VB, Mishkorudnaya MI. [Spectrophotometric determination of the content of lipid hydroperoxes in the blood plasma]. Lab Delo. 1983;(3)33-36. [Article in Russian]. 22. 22.Gavrilov VB, Gavrilova AR, Mazhul' LM. [Methods of determining lipid peroxidation products in the serum using a thiobarbituric acid test]. Vopr Med Khim. 1987;33(1):11822. [Article in Russian].

23. Cherniauskene RCh, Varshkiavichene ZZ, Gribauskas PS. [Simultaneous fluorometric determination of the concentrations of vitamins E and A in blood serum]. Lab Delo. 1984;(6):362-5.[Article in Russian].

24. Klebanov GI, Babenkova IV, Teselkin IuO, Komarov OS, Vladimirov IuA. [Evaluation of the antioxidative activity of blood plasma using yolk lipoproteins]. Lab Delo. 1988;(5):5962. [Article in Russian]. 